University of Nebraska - Lincoln

DigitalCommons@University of Nebraska - Lincoln

Biological Systems Engineering: Papers and

Publications

Biological Systems Engineering

$5-2013$

\title{
HYDRAULIC CONDITIONS REQUIRED TO NOT MOVE UNCONSOLIDATED SURFACE MATERIAL LOCATED WITHIN FEEDLOTS
}

John E. Gilley

Adjunct Professor, Biological Systems Engineering, john.gilley@ars.usda.gov

Gregory D. Boone

University of Nebraska-Lincoln

David B. Marx

University of Nebraska-Lincoln, david.marx@unl.edu

Follow this and additional works at: https://digitalcommons.unl.edu/biosysengfacpub

Part of the Bioresource and Agricultural Engineering Commons

Gilley, John E.; Boone, Gregory D.; and Marx, David B., "HYDRAULIC CONDITIONS REQUIRED TO NOT MOVE UNCONSOLIDATED SURFACE MATERIAL LOCATED WITHIN FEEDLOTS" (2013). Biological Systems Engineering: Papers and Publications. 323.

https://digitalcommons.unl.edu/biosysengfacpub/323

This Article is brought to you for free and open access by the Biological Systems Engineering at DigitalCommons@University of Nebraska - Lincoln. It has been accepted for inclusion in Biological Systems Engineering: Papers and Publications by an authorized administrator of DigitalCommons@University of Nebraska Lincoln. 


\title{
HYDRAULIC CONDITIONS REQUIRED TO NOT MOVE UNCONSOLIDATED SURFACE MATERIAL LOCATED WITHIN FEEDLOTS
}

\author{
J. E. Gilley, G. D. Boone, D. B. Marx
}

\begin{abstract}
Beef cattle feedlots contain unconsolidated surface material that accumulates within feedlot pens during a feeding cycle. Runoff from feedlot surfaces is diverted into settling basins. The storage capacity of the settling basins will be substantially reduced if large quantities of solid material are transported in runoff from the feedlot surfaces. The objective of this study was to identify the hydraulic conditions that will not move unconsolidated surface material located within feedlots in order to minimize sediment transport. Selected sizes and a composite sample of unconsolidated surface material were placed within $0.75 \mathrm{~m}$ wide by $4.0 \mathrm{~m}$ long metal frames. Flow was then introduced at the top of the frames in successive increments. The discharge rate and flow velocity necessary to cause movement of unconsolidated surface material was measured. Hydraulic measurements were used to determine the ratio of critical flow depth to particle diameter, critical flow rate, critical flow velocity, critical shear velocity, critical Reynolds number, critical shear stress, critical dimensionless shear stress, and critical boundary Reynolds number. Measurements of these parameters for the composite material were 0.556, $0.499 \mathrm{~L} \mathrm{~s}^{-1}, 0.0787 \mathrm{~m} \mathrm{~s}^{-1}, 0.0643 \mathrm{~m} \mathrm{~s}^{-1}, 695,4.12 \mathrm{~Pa}, 0.0436$, and 1040, respectively. Darcy-Weisbach roughness coefficients were calculated for each particle size class and the composite sample at varying flow rates. The information presented in this study can be used to identify the hydraulic conditions required to not move unconsolidated surface material located within feedlots in order to minimize sediment transport.
\end{abstract}

Keywords. Feedlots, Flow measurement, Flow resistance, Hydraulic roughness, Manure management, Manure runoff, Runoff, Sediment detention, Sediment discharge, Sedimentation.

$\mathrm{E}$ nvironmental regulations have been established that define acceptable standards for runoff control from open-lot livestock production facilities. With present regulations, there is usually no direct hydrologic connection between feedlot runoff and a downstream water body. A combination of clean water diversion, irrigations systems, settling basins, and runoff collection ponds are typically used for feedlot runoff control.

Runoff collection ponds prevent sediment and other pollutants from entering streams and lakes, and the ponds store runoff until it can be land applied (ASABE Standards, 2009). Construction, operation, and maintenance requirements for feedlot runoff containment structures have been established (Ham, 1999, 2002; Parker et al., 1999).

Submitted for review in December 2011 as manuscript number SW 9546; approved for publication by the Soil \& Water Division of ASABE in May 2013.

Mention of company or trade names is for description only and does not imply endorsement by the USDA. The USDA is an equal opportunity provider and employer.

The authors are John E. Gilley, ASABE Member, Research Agricultural Engineer, USDA-ARS, Gregory D. Boone, Former Student, Department of Biological Systems Engineering, and David B. Marx, Professor, Department of Statistics, University of Nebraska, Lincoln, Nebraska. Corresponding author: John E. Gilley, USDA-ARS, 251 Chase Hall, University of Nebraska, Lincoln, NE 68583-0934; phone: 402-472-2975; e-mail: john.gilley@ars.usda.gov.
The size of runoff collection ponds is influenced by the quantity of suspended material transported in runoff from the feedlot. Both erosion and size distribution of sediment from feedlot surfaces are significantly influenced by runoff rate (Gilley et al., 2011). Eroded materials that accumulate within a containment structure may substantially reduce the storage capacity. As a result, sediment deposited within a collection pond must be removed periodically to maintain the required storage capacity. Sediment deposition within feedlot storage facilities could be reduced if better management practices for minimizing sediment transport are implemented. The objective of this study was to identify the hydraulic conditions that will not move unconsolidated surface material located within feedlots in order to minimize sediment transport.

A standard feedlot management objective is to maintain a black interface layer of compacted manure above the mineral soil to enhance surface runoff and limit infiltration, thus helping to reduce wet feedlot conditions (Mielke et al., 1974; Mielke and Mazurak, 1976). Beef cattle feedlots contain unconsolidated surface material (loose manure pack) and consolidated subsurface material (compacted manure and underlying layers) (Woodbury et al., 2001). Manure is usually removed from the feedlot once or twice each year between cattle production cycles. Manure enrichment, compaction, and moisture content may vary across the pen surface during the production cycle. The 
location of feed and water sources has been shown to significantly influence feedlot soil characteristics (Gilley et al., 2008).

Feedlot pen surfaces become muddy during high moisture conditions, and the health and performance of cattle may be affected. The stirring action of cattle's hooves mixes the soil and manure, creating a feedlot management problem (Clanton et al., 2005). The quantity of unconsolidated material on the feedlot surface usually increases following a significant rainfall event but is reduced as the feedlot dries and cattle compact the surface.

The quantity and characteristics of sediment transported in runoff from feedlot surfaces may be influenced by the amount of unconsolidated material contained on the feedlot surface. Removing all of the accumulated manure to maintain optimum feedlot pen conditions is time consuming and expensive since soil feedlot materials typically contain only $25 \%$ to $30 \%$ volatile solids (Parker et al., 2004). One management alternative that has been proposed to provide a healthier environment for livestock is the periodic removal of unconsolidated surface material from feedlot surfaces. At present, little information is available concerning temporal changes in the amount of unconsolidated material contained on feedlot surfaces.

\section{Hydraulic Equations}

For steady flow conditions:

$$
Q=V A
$$

where $Q$ is the flow rate, $V$ is the mean flow velocity, and $A$ is the cross-sectional flow area. Average flow depth $(y)$ for overland or sheet flow may be estimated as:

$$
y=\frac{Q}{V b}
$$

where $b$ is the flow width. In the present study, flow depth was determined indirectly using equation 2 and measurements of $Q$ and $V$. Flow width was a constant value of $0.75 \mathrm{~m}$, the width of the flow plane.

The Reynolds number for open channel flow (Rn), which is used to describe the ratio of inertial forces to viscous forces, is expressed as (Chow, 1959):

$$
\mathrm{Rn}=\frac{V R}{v}
$$

where $v$ is the kinematic viscosity, and $R$ is the hydraulic radius. Kinematic viscosity can be determined if water temperature is known. The Reynolds number that causes unconsolidated surface material to begin to move is defined as the critical Reynolds number.

Hydraulic radius $(R)$ is given as:

$$
R=\frac{A}{P}
$$

where $P$ is the wetted perimeter. For a rectangular area of width $b$ :

$$
R=\frac{b y}{b+2 y}
$$

For overland flow conditions, where flow width is much greater than flow depth, hydraulic radius can be assumed to be approximately equal to flow depth. Thus, for broad sheet flow:

$$
\mathrm{Rn} \approx \frac{V y}{v} \approx \frac{q}{v}
$$

where flow rate per unit width $(q)$ is given as:

$$
q=\frac{Q}{b}
$$

Water flowing over a surface exerts a force on the surface that acts in the direction of flow. This force per unit wetted area is called shear stress $(\tau)$ and is expressed as:

$$
\tau=\gamma R S
$$

where $\gamma$ is the specific weight of water, and $S$ is the energy or friction slope. It was assumed in this study that normal flow conditions were present and that $S$ was equal to the slope of the overland flow plane. In the present study, critical shear stress is defined as the force per unit wetted area required to initiate movement of unconsolidated surface materials. The most dependable data concerning particle movement have resulted from visual observations.

Shear velocity $\left(V^{*}\right)$ is given as:

$$
V^{*}=(g R S)^{1 / 2}
$$

where $g$ is the gravitational acceleration. Shear velocity at the threshold condition for movement of unconsolidated surface material is defined as critical shear velocity. The beginning of motion for unconsolidated surface material can be identified using dimensionless shear stress $\left(F^{*}\right)$, which is defined as:

$$
F^{*}=\frac{\tau_{c}}{\left(\gamma_{s}-\gamma\right) D}
$$

where $\gamma_{s}$ is the specific weight of unconsolidated surface material, and $D$ is the particle diameter. The beginning of motion for unconsolidated surface material is also a function of the boundary Reynolds number $\left(\mathrm{Rn}^{*}\right)$, which is a dimensionless parameter expressed as:

$$
\mathrm{Rn}^{*}=\frac{V_{c}^{*} D}{v}
$$

The Darcy-Weisbach equation has been widely used to describe flow characteristics. Under uniform flow conditions, the Darcy-Weisbach friction coefficient is given as (Chow, 1959):

$$
f=\frac{8 g R S}{V^{2}}
$$


Table 1. Regression equations for Darcy-Weisbach roughness coefficients as affected by Reynolds number for the unconsolidated surface material.

\begin{tabular}{|c|c|c|c|c|c|}
\hline $\begin{array}{c}\text { Mean } \\
\text { Particle } \\
\text { Diameter }\end{array}$ & $\begin{array}{c}\text { Darcy- } \\
\text { Weisbach } \\
\text { Roughness }\end{array}$ & \multirow{2}{*}{$\begin{array}{c}\text { Reynolds } \\
\text { Number }\end{array}$} & \multicolumn{2}{|c|}{$\begin{array}{c}\text { Regression } \\
\text { Coefficients }^{[a]}\end{array}$} & \multirow[b]{2}{*}{$r^{2}$} \\
\hline $\begin{array}{l}\text { Diameter } \\
(\mathrm{mm})\end{array}$ & $\begin{array}{l}\text { Roughness } \\
\text { Coefficient }\end{array}$ & & $a$ & $b$ & \\
\hline 4.76 & 0.37 to 6.42 & 20 to 281 & 3.53 & -0.009 & 0.72 \\
\hline 9.53 & 1.74 to 39 & 313 to 2507 & 25.1 & -0.001 & 0.82 \\
\hline 19.1 & 3.32 to 43 & 109 to 1061 & 46.6 & -0.002 & 0.93 \\
\hline 47.5 & 15 to 60 & 178 to 1473 & 66.9 & -0.0009 & 0.87 \\
\hline $\begin{array}{c}\text { Composite } \\
(15.2)\end{array}$ & 2.21 to 68 & 124 to 706 & 92.5 & -0.006 & 0.88 \\
\hline
\end{tabular}

[a] Regression coefficients $a$ and $b$ are used in the regression equation:

Darcy-Weisbach roughness coefficient $=a \exp (b$ Reynolds number $)$.

The Manning formula is often used in open channel hydraulics. The Darcy-Weisbach friction coefficient can be related to Manning's roughness coefficient $(n)$ using the equation:

$$
f=\frac{116 n^{2}}{R^{1 / 3}}
$$

For broad sheet flow conditions, $y$ can be calculated from the equation:

$$
y=\left[\frac{f q^{2}}{8 g S}\right]^{1 / 3}
$$

If information on rainfall excess is available or can be estimated, the Reynolds number can be calculated from equation 6, and the Darcy-Weisbach roughness coefficient can be determined from table 1. Water depth can then be estimated using equation 14, and flow velocity for broad sheet flow conditions can be determined from equation 6 . Once estimates for water depth and velocity are available, other important hydraulic parameters can be determined.

\section{Materials ANd Methods Manure CharaCteristics}

Beef cattle manure was collected from feedlot pens located at the U.S. Meat Animal Research Center near Clay Center, Nebraska. Calves born during the spring of 2009 were placed in the pens in October 2009, and the cattle were fed a corn-based diet. Soil was excavated at an offsite location from the C-horizon of a Hastings soil (fine, smectitic, mesic Pachic Argiustolls). This soil was placed on the feedlot surface following each pen cleaning cycle, which usually occurred twice a year. The feedlot pens on which manure was collected did not contain mounds.

The size distribution of unconsolidated surface material is shown in figure 1. It can be seen from figure 1 that the particle size for which $50 \%$ of the surface material is finer is $15.2 \mathrm{~mm}$. Special screens were fabricated to separate the unconsolidated surface material into individual size classes. Unconsolidated material lying on the feedlot surface was first transported to a set of nested sieves located above a $19 \mathrm{~L}$ bucket. The unconsolidated surface material was then sieved by hand through successively smaller sieves. The material that remained on a particular sieve was placed in a

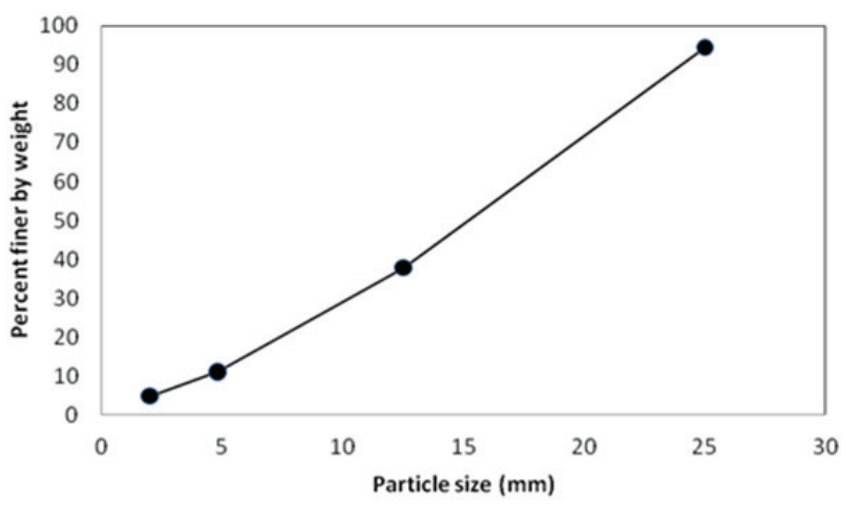

Figure 1. Size distribution of unconsolidated surface material.

19 L bucket reserved for a given size class. A micrometer was used to measure the diameter of representative particles remaining on the largest sieve. The diameter of each of the other size classes was reported as the average of the size through which the material passed and the size of the sieve on which it was retained.

Recently deposited "fresh" manure soon becomes incorporated as part of the unconsolidated surface material. The relatively small amount of recently deposited manure contained on the feedlot surface was not included in this study. The mean water content of the manure used in the hydraulic tests was $7.03 \%$.

Particle density influences the settling velocity of solids contained in feedlot runoff effluent. A mean particle density of $1.63 \mathrm{~g} \mathrm{~cm}^{-3}$ was obtained for the unconsolidated surface material using the laboratory procedure of Blake and Hartge (1986). Particle densities of sediment contained in runoff from earthen feedlots were reported by Pepple et al. (2011) and Gilbertson and Nienaber (1973) to be 1.89 and $1.95 \mathrm{~g} \mathrm{~cm}^{-3}$, respectively. A mean particle density of $1.47 \mathrm{~g}$ $\mathrm{cm}^{-3}$ was measured for sediment from feedlots with concrete surfaces (Pepple et al., 2011). In most mineral soils, mean particle density is 2.6 to $2.7 \mathrm{~g} \mathrm{~cm}^{-3}$ (Hillel, 1971).

\section{STUDY Site ChaRACTERISTICS}

The feedlot manure was transported for testing to the University of Nebraska Rogers Memorial Farm located $18 \mathrm{~km}$ east of Lincoln, Nebraska. The Aksarben silty clay loam soil (fine, smectitic, mesic Typic Argiudoll) on which the manure was placed is moderately well drained, and permeability is moderately slow. The study site had been cropped using a grain sorghum (Sorghum bicolor (L.) Moench), soybean (Glycine $\max (\mathrm{L}$.$) Merr.), winter wheat$ (Triticum aestivum L. cv. Pastiche) rotation. A long-term continuous no-till management system with controlled wheel traffic was used on the farm. The study area was planted to winter wheat during the 2009-2010 cropping season. The winter wheat was clipped by hand near the soil surface at the time of plot establishment.

Clark et al. (1975) reported that the mean slope of selected feedlots in the southern Great Plains ranged from $1.3 \%$ near Pratt, Kansas, to $9.0 \%$ near Mead, Nebraska. Gilley et al. (2009) conducted tests on a feedlot near Clay Center, Nebraska, that had a mean slope of $4.8 \%$. The mean 
slope of the study site used in this investigation was 5.1\%.

\section{Plot Preparation}

Twelve $0.75 \mathrm{~m}$ wide by $4 \mathrm{~m}$ long hydraulic test sections were established, with the longer plot dimension parallel to the slope in the direction of overland flow. Field tests were conducted on manure obtained from each of five size classes and a composite sample that had not been sieved. The manure was placed on the plots to a depth of approximately $6 \mathrm{~cm}$. Each plot was abandoned, and additional tests were performed on adjoining plots after the hydraulic measurements were made.

Each of the five size classes and the composite treatment was replicated twice. Two replicated tests (separate plots) were evaluated for each of the five size classes and the composite treatment. The flow characteristics required to cause incipient motion for a particular size class were measured in this study. Once critical flow rate had been reached on a given plot, rill formation began and broad sheet flow conditions were no longer present.

\section{Hydraulic Testing Procedures}

Water used during the tests was obtained from an irrigation well located near the experimental site. Following manure application, water which had an EC of $0.79 \mathrm{dS} \mathrm{m}^{-1}$ and a $\mathrm{pH}$ of 7.4 was added to the plots with a hose until runoff began to provide more uniform antecedent soil water conditions among treatments. Plot borders channeled runoff into a sheet metal lip that emptied into a collection trough that extended across the bottom of each plot. Runoff was then diverted into a $0.18 \mathrm{~m}$ HS flume on which a stage recorder was mounted to measure discharge rate. Kinematic viscosity was determined for each run from measurements of water temperature.

Inflow was introduced at the upstream end of the $0.75 \mathrm{~m}$ by $4.0 \mathrm{~m}$ overland flow plane in successive increments. Simulated rainfall was not used during the study. The inflow device was a $2.5 \mathrm{~cm}$ diameter plastic tube that extended across the top of the plot. Only one plastic tube was used at a time, but several separate tubes were employed during the testing procedure. Several holes were drilled into the plastic tubes to allow water to be introduced uniformly across the plot surface. A gate valve and associated pressure gauge located on the inlet to the plastic tubes were adjusted to provide the desired flow rate. A narrow mat was placed on the soil surface beneath the inflow device to prevent scouring and distribute flow more uniformly across the plot surface.

Flow addition for each inflow increment occurred only after steady-state runoff conditions for the previous inflow increment became established and samples for sediment analyses had been collected. Steady-state runoff conditions were determined using the stage recorder and flume. Critical flow rate, which was identified visually, occurred when significant amounts of unconsolidated surface material were dislodged and transported from their original location. Concentrated flow channels formed immediately after the unconsolidated surface material was removed. The surface materials were usually dislodged near the upper portion of the plot soon after the critical flow rate had been introduced. Since the surface materials were unconsolidated and relatively large in comparison to soil materials, it was not difficult to identify incipient particle motion.

Once steady-state runoff conditions had become established, line sources of fluorescent dye were injected across the test section at downslope distances of 0.5 and $3.5 \mathrm{~m}$. The time required for the dye concentration peaks to move across the overland flow plane and through the runoff collection system was determined using a fluorometer and stop watch. Mean flow velocity was calculated by dividing the distance between the two line sources of dye $(3.0 \mathrm{~m})$ by the difference in travel time between the two dye concentration peaks. Two measurements of flow velocity were made for each flow rate.

The largest particle size class for which hydraulic measurements were made was $47.5 \mathrm{~mm}$. The flow rates provided by the existing inflow equipment were not large enough to cause movement of the $47.5 \mathrm{~mm}$ materials. Therefore, critical hydraulic variables were not reported for this size class.

\section{STATISTICAL ANALYSES}

The effects of mean particle diameter on field measurements of critical flow rate and critical flow velocity were determined using the least significant difference (LSD) test (SAS, 2011). Measurements of critical flow rate and critical flow velocity from the replicated plots used for each particle diameter were included in the analyses and were treated as repeated measures. A probability level $<0.05$ was considered significant.

\section{RESULTS AND DISCUSSION}

Critical flow rate and critical flow velocity measurements for each of the particle size classes are presented in table 2. Values for each of the replications are presented to provide information on the variability between field measurements. Critical flow rate and flow velocity measurements were used to calculate other important hydraulic variables discussed below.

\section{RATIO OF CRITICAL FLOW DEPTH To PARTicle Diameter}

Particles with diameters of $1.59,4.76,9.53$, and $19.1 \mathrm{~mm}$ had ratios of critical flow depth to particle dia-

Table 2. Critical flow rate and critical flow velocity measurements for selected size classes.

\begin{tabular}{cccc}
\hline $\begin{array}{c}\text { Mean Particle } \\
\text { Diameter } \\
(\mathrm{mm})\end{array}$ & Replication & $\begin{array}{c}\text { Critical } \\
\text { Flow Rate } \\
\left(\mathrm{L} \mathrm{s}^{-1} \times 10^{-2}\right)\end{array}$ & $\begin{array}{c}\text { Critical } \\
\text { Flow Velocity } \\
\left(\mathrm{m} \mathrm{s}^{-1} \times 10^{-2}\right)\end{array}$ \\
\hline 1.59 & 1 & 0.0283 & 13.8 \\
1.59 & 2 & 0.0283 & 6.02 \\
4.76 & 1 & 5.48 & 2.79 \\
4.76 & 2 & 3.90 & 6.10 \\
9.53 & 1 & 24.6 & 3.86 \\
9.53 & 2 & 28.3 & 7.16 \\
19.1 & 1 & 86.2 & 9.25 \\
19.1 & 2 & 110 & 8.99 \\
Composite $(15.2)$ & 1 & 71.4 & 8.23 \\
Composite $(15.2)$ & 2 & 28.3 & 7.52 \\
\hline
\end{tabular}


Table 3. Critical hydraulic characteristics of unconsolidated surface material.

\begin{tabular}{|c|c|c|c|c|}
\hline $\begin{array}{l}\text { Mean Particle } \\
\text { Diameter } \\
(\mathrm{mm})\end{array}$ & $\begin{array}{l}\text { Ratio of } \\
\text { Critical Flow Depth } \\
\text { to Particle Diameter }\end{array}$ & $\begin{array}{c}\text { Critical } \\
\text { Flow Rate }^{[\mathrm{a}]} \\
\left(\mathrm{L} \mathrm{s}^{-1} \times 10^{-2}\right)\end{array}$ & $\begin{array}{c}\text { Critical } \\
\text { Flow Velocity }^{[\mathrm{a}]} \\
\left(\mathrm{m} \mathrm{s}^{-1} \times 10^{-2}\right)\end{array}$ & $\begin{array}{c}\text { Critical } \\
\text { Shear Velocity } \\
\left(\mathrm{m} \mathrm{s}^{-1} \times 10^{-2}\right)\end{array}$ \\
\hline 1.59 & 0.002 & $0.0283 \mathrm{c}$ & $9.91 \mathrm{a}$ & 0.138 \\
\hline 4.76 & 0.296 & $4.69 \mathrm{c}$ & $4.44 \mathrm{a}$ & 2.65 \\
\hline 9.53 & 0.673 & $26.5 \mathrm{bc}$ & $5.51 \mathrm{a}$ & 5.62 \\
\hline 19.1 & 0.751 & $98.1 \mathrm{a}$ & $9.12 \mathrm{a}$ & 8.31 \\
\hline Composite (15.2) & 0.556 & $49.9 \mathrm{~b}$ & $7.87 \mathrm{a}$ & 6.43 \\
\hline Mean Particle & & Critical & Critical Dimensionless & \\
\hline $\begin{array}{l}\text { Diameter } \\
(\mathrm{mm})\end{array}$ & $\begin{array}{c}\text { Critical } \\
\text { Reynolds Number }\end{array}$ & $\begin{array}{c}\text { Shear Stress } \\
(\mathrm{Pa})\end{array}$ & $\begin{array}{l}\text { Shear Stress } \\
\left(\times 10^{-2}\right)\end{array}$ & $\begin{array}{l}\text { Critical Boundary } \\
\text { Reynolds Number }\end{array}$ \\
\hline 1.59 & 0.418 & 0.002 & 0.019 & 2.43 \\
\hline 4.76 & 62.1 & 0.699 & 2.36 & 126 \\
\hline 9.53 & 358 & 3.14 & 5.30 & 552 \\
\hline 19.1 & 1210 & 6.89 & 5.80 & 1530 \\
\hline Composite (15.2) & 695 & 4.12 & 4.36 & 1040 \\
\hline
\end{tabular}

meter of $0.002,0.296,0.673$, and 0.751 , respectively (table 3 ). The composite sample, with a mean particle diameter of $15.2 \mathrm{~mm}$, had a ratio of critical flow depth to particle diameter of 0.556 . Thus, all of the size classes had ratios of critical flow depth to particle diameter less than one.

A critical flow depth to particle diameter ratio less than one indicates that the diameter of the particles was greater than critical flow depth. Thus, the unconsolidated surface material was dislodged by overland flow before individual particles became submerged. The submerged weight of particles, lift forces, and drag forces may all influence movement of unanchored particles (Chow, 1959). The density of the unconsolidated surface material was $1.63 \mathrm{~g}$ $\mathrm{cm}^{-3}$, which indicates that a lift or buoyancy force did not influence incipient motion. Therefore, drag forces were responsible for initiating incipient motion.

\section{Critical Flow Rate}

Mean particle diameter significantly affected measurements of critical flow rate, which increased from $0.0283 \times 10^{-2}$ to $98.1 \times 10^{-2} \mathrm{~L} \mathrm{~s}^{-1}$ as particle diameter varied from 1.59 to $19.1 \mathrm{~mm}$ (table 3 ). The composite sample, with a mean diameter of $15.2 \mathrm{~mm}$, had a critical flow rate of $0.499 \mathrm{~L} \mathrm{~s}^{-1}$. The critical flow rate of $98.1 \times 10^{-2} \mathrm{~L} \mathrm{~s}^{-1}$ measured for the surface with a mean particle diameter of $19.1 \mathrm{~mm}$ was significantly larger than the critical flow rates obtained on the other surfaces. No significant differences in critical flow rates were found among surfaces with mean particle diameters varying from 1.59 to $9.53 \mathrm{~mm}$.

\section{Critical Flow Velocity}

Critical flow velocities were not significantly affected by mean particle diameter (table 3). Measurements of critical flow velocity varied from $4.44 \times 10^{-2}$ to $9.12 \times 10^{-2} \mathrm{~m} \mathrm{~s}^{-1}$ for the particle size classes with diameters varying from 4.76 to $19.1 \mathrm{~mm}$. A critical flow velocity of $7.87 \times 10^{-2} \mathrm{~m} \mathrm{~s}^{-1}$ was measured for the composite material having a mean diameter of $15.2 \mathrm{~mm}$.

\section{Critical Shear Velocity}

Critical shear velocity increased in a linear fashion with particle diameter, with values varying from $0.138 \times 10^{-2}$ to $8.31 \times 10^{-2} \mathrm{~m} \mathrm{~s}^{-1}$ as particle diameter ranged from 1.59 to $19.1 \mathrm{~mm}$ (table 3 and fig. 2). A critical shear velocity of

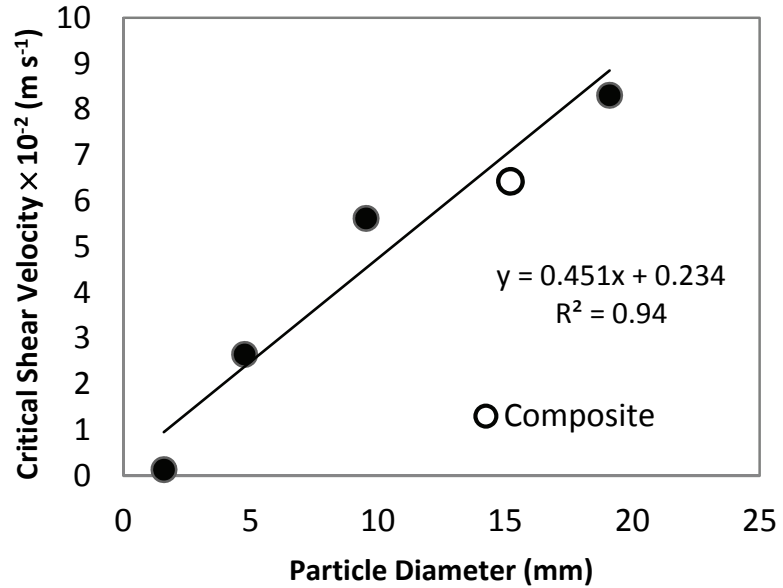

Figure 2. Critical shear velocity as affected by the diameter of the unconsolidated surface material. The value for the composite sample was not included in the derivation of the regression equation.

$6.43 \times 10^{-2} \mathrm{~m} \mathrm{~s}^{-1}$ was measured for the composite sample. The regression relationship shown in figure 2 was derived using information collected for four individual size classes. The value for the composite sample is shown in figure 2 for purposes of comparison, but it was not used in the derivation of the regression equation.

\section{Critical Reynolds Number}

Critical Reynolds number can be used to estimate the flow rate required to initiate particle movement. Drag forces were responsible for initiating movement of the unconsolidated surface material. The critical Reynolds number of 0.418 obtained for the $1.59 \mathrm{~mm}$ size class indicates that very little flow is necessary to cause particle movement for smaller-diameter unconsolidated surface material. As particle diameter varied from 1.59 to $19.1 \mathrm{~mm}$, critical Reynolds number increased in a linear fashion from 0.418 to 1210 (table 3 and fig. 3). The composite sample, with a mean particle diameter of $15.2 \mathrm{~mm}$, had a critical Reynolds number of 695 .

\section{CRITICAL SheAR STRESS}

Forces of static friction act between surfaces at rest with respect to each other. The maximum force of static friction 


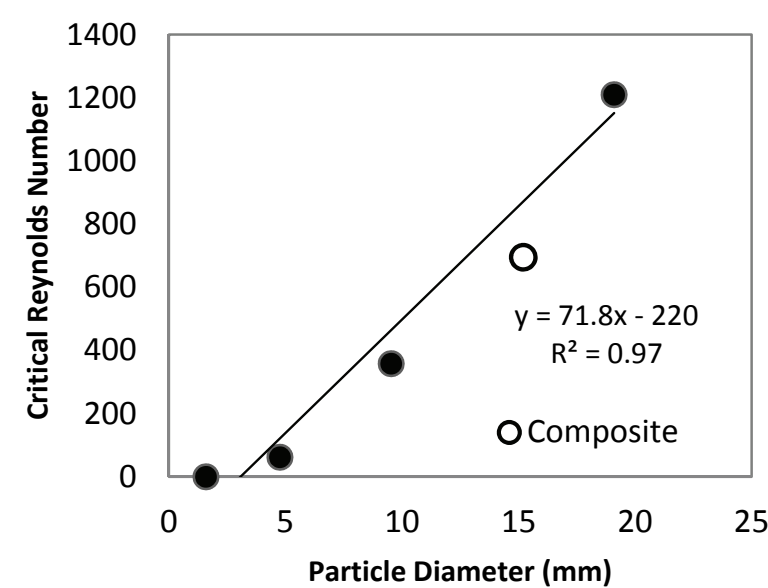

Figure 3. Critical Reynolds number as affected by the diameter of the unconsolidated surface material. The value for the composite sample was not included in the derivation of the regression equation.

is the same as the smallest force necessary to initiate particle motion. Critical shear stress is defined as the force per unit area required to initiate movement of unconsolidated surface material. The critical shear stress value of $0.002 \mathrm{~Pa}$ measured for the $1.59 \mathrm{~mm}$ diameter size class indicates that minimal shear stress is required to initiate particle movement for unconsolidated surface material with small diameters. Critical shear stress increased in a linear fashion from 0.002 to $6.89 \mathrm{~Pa}$ as particle diameter varied from 1.59 to $19.1 \mathrm{~mm}$ (table 3 and fig. 4). The composite sample, with a mean particle diameter of $15.2 \mathrm{~mm}$, had a critical shear stress of $4.12 \mathrm{~Pa}$.

Gilley et al. (1993) reported critical shear stress values for 29 soils located throughout the U.S. where crop residues had been removed and moldboard plowing and disking had occurred. Runoff measurements were made on selected sites where simulated rainfall was applied to preformed rills. Critical shear stress values varied from 1.73 to $10.6 \mathrm{~Pa}$, and the mean value was $4.35 \mathrm{~Pa}$. Critical

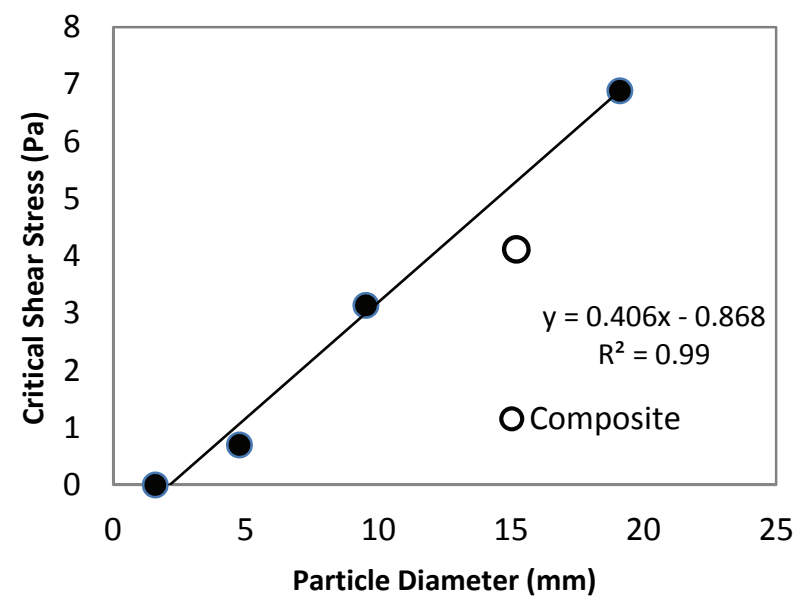

Figure 4. Critical shear stress as affected by the diameter of the unconsolidated surface material. The value for the composite sample was not included in the derivation of the regression equation. shear stress measurements obtained in the present study for the 9.53 and $19.1 \mathrm{~mm}$ size classes and the composite material were within the range of values reported by Gilley et al. (1993). The unconsolidated surface material consisting of 1.59 and $4.76 \mathrm{~mm}$ size classes had critical shear stress values less than those reported by Gilley et al. (1993), which indicates that smaller-diameter unconsolidated surface material is more easily detached than selected cropland soils that had been recently tilled.

\section{CRITICAL Dimensionless SHEAR STRESS AND CRITICAL BOUNDARY REYNOLDS NUMBER}

The Shields diagram is used to identify the beginning of motion for noncohesive materials by relating critical dimensionless shear stress to critical boundary Reynolds number (Simons and Senturk, 1976). Critical dimensionless shear stress for the individual size classes varied from $0.019 \times 10^{-2}$ to $5.80 \times 10^{-2}$ (table 3 ). The composite sample had a critical dimensionless shear stress of $4.36 \times 10^{-2}$.

Critical boundary Reynolds number increased in a linear fashion from 2.43 to 1530 as particle diameter increased from 1.59 to $19.1 \mathrm{~mm}$ (table 3 and fig. 5). The composite sample, with a mean particle diameter of $15.2 \mathrm{~mm}$, had a critical boundary Reynolds number of 1040 .

For conditions where boundary Reynolds number is greater than 70, Simons and Senturk (1976) described the flow boundary as completely rough and reported that critical dimensionless shear stress is independent of boundary Reynolds number and is equal to 0.06 . In the present study, a mean value for critical dimensionless shear stress of 0.04 was found for conditions where critical boundary Reynolds number was greater than 70 (table 3 ).

\section{DARCY-WeisbaCh Roughness COEFFICIENTS}

Hydraulic roughness coefficients are used to calculate overland flow velocities, which can be used to estimate time of concentration or travel times. Roughness coefficients are also used in the routing of runoff hydro-

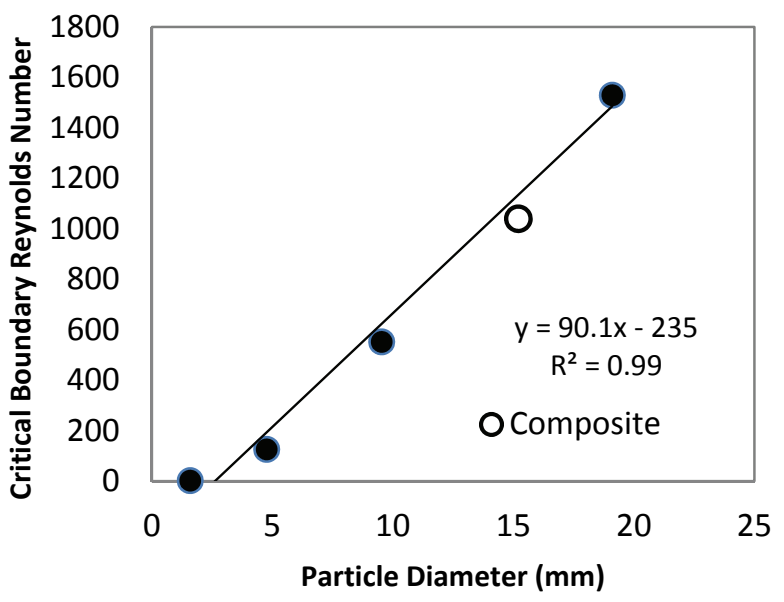

Figure 5. Critical boundary Reynolds number as affected by the diameter of the unconsolidated surface material. The value for the composite sample was not included in the derivation of the regression equation. 


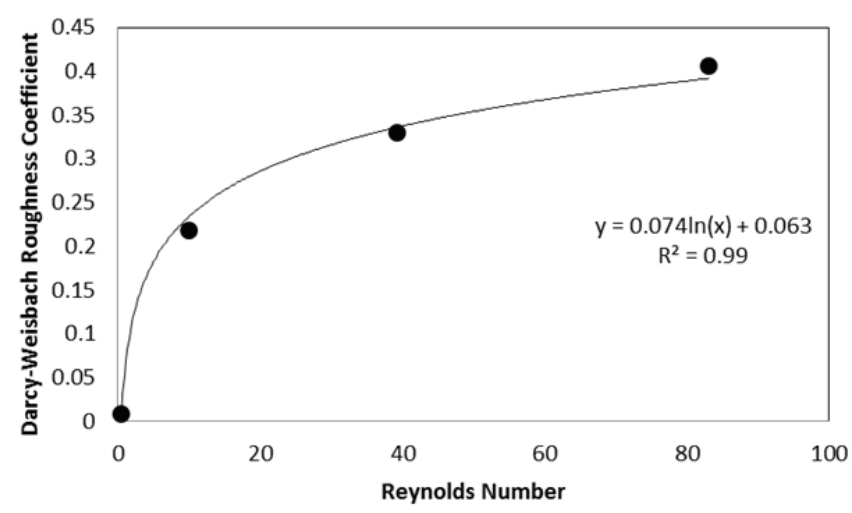

Figure 6. Darcy-Weisbach roughness coefficient as affected by Reynolds number for unconsolidated surface material with a mean diameter of $1.59 \mathrm{~mm}$.

graphs over the land surface (Engman, 1986). In this study, field hydraulic measurements were used to calculate DarcyWeisbach roughness coefficients for each of the particle size classes and the composite sample.

The ratio of critical flow depth to particle diameter for the surface containing $1.59 \mathrm{~mm}$ diameter materials was 0.002 (table 3). Thus, the surface area on which overland flow was occurring was much less than the total plot area. The submerged plot area increased as flow rate (Reynolds number) increased, causing hydraulic resistance to become greater. As a result, Darcy-Weisbach roughness coefficients increased with Reynolds number on the surface containing $1.59 \mathrm{~mm}$ diameter materials (fig. 6). It did not appear that surface tension significantly influenced flow hydraulics for any of the particle size classes, including the surface containing $1.59 \mathrm{~mm}$ diameter materials.

The decrease in Darcy-Weisbach roughness coefficient with Reynolds number shown in figure 7 for the composite sample is characteristic of particle size classes varying from 4.76 to $47.5 \mathrm{~mm}$. A much larger portion of the unconsolidated surface materials was submerged as critical flow rate was reached for the surfaces containing the larger particle size classes. As flow rate and water depth increased, the submerged roughness elements had much less of an effect on hydraulic resistance, causing roughness coefficients to decrease. Regression equations for estimating Darcy-Weisbach roughness coefficients for particle

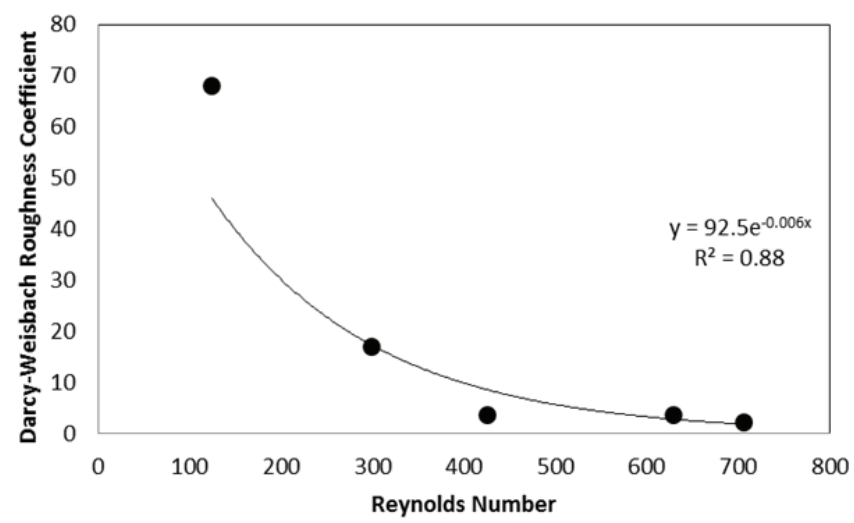

Figure 7. Darcy-Weisbach roughness coefficient as affected by Reynolds number for the composite unconsolidated surface material with a mean diameter of $15.2 \mathrm{~mm}$. size classes of $4.76,9.53,19.1$, and $47.5 \mathrm{~mm}$ and the composite material are shown in table 1 .

Abrahams et al. (1986) conducted a study to examine the relation between the Darcy-Weisbach friction factor and Reynolds number for overland flow on six runoff plots in southern Arizona. As overland flow increased, surface roughness elements were progressively inundated, thereby altering flow resistance. The relationship of friction factor and Reynolds number had two basic shapes: convex upward and negatively sloping. The progressive inundation of roughness elements initially caused Darcy-Weisbach friction factors to increase. In turn, the progressive increase in flow depth over already inundated parts of the surface as discharge increased resulted in a decrease in friction factors. These same two processes appeared to have also occurred in the present investigation.

Foster et al. (1968) reported Darcy-Weisbach roughness coefficients ranging from 0.09 to 2.52 . Surface roughness on the fallow surfaces used by Foster et al. (1968) on which rainfall had occurred would have been expected to be relatively small. In comparison, surface roughness was much larger on the plot surfaces containing feedlot materials examined in the present study. As a result, DarcyWeisbach roughness coefficients in the present study varied from 0.37 to 68 (table 1 ).

Woolhiser et al. (1970) calculated Darcy-Weisbach roughness coefficients for four moderately grazed small rangeland watersheds. They found that for laminar flow, the Darcy-Weisbach friction factor could be calculated from the following equation:

$$
f=\frac{7000}{\mathrm{Rn}}
$$

Using equation 15 , an $f$ value of 23 is estimated for a Reynolds number value of 300 . The equation for the composite material shown in table 1 yields a DarcyWeisbach friction factor estimate of 15 for a Reynolds number value of 300 .

\section{Feedlot Management Considerations}

It can be seen from equation 8 that shear stress is directly proportional to slope gradient. Shear stress can be reduced if a feedlot is established in an area with a smaller slope gradient. However, it is important that a feedlot be placed on a site that provides sufficient drainage to allow the feedlot surface to dry quickly following a precipitation event.

Shear stress is also directly proportional to hydraulic radius, which is approximately equal to flow depth for broad sheet flow conditions. It can be seen from equation 14 that water depth increases with flow rate. Therefore, reducing the length of overland flow by shortening pen length would also reduce flow rate and shear stress at the bottom of a feedlot pen.

Mounds constructed of soil within feedlot pens provide a location for cattle to stand or lay during wet periods. Mounds are an economical alternative to bedding, concrete lots, or confinement buildings. Slope gradients on the sides of the mound are much larger than in the rest of the pen. As 
a result, unconsolidated surface material is usually transported from the mound by overland flow and then deposited in areas at the base of the mound having much smaller slope gradients. Therefore, much of the unconsolidated surface material in pens containing a mound is concentrated in the area below the mound. The water content of unconsolidated surface material surrounding the mound is usually larger than the material located on the mound. The periodic removal of unconsolidated surface material from the feedlot surface could reduce the amount of material deposited in runoff control structures.

Seasonal rainfall patterns occur in many areas where beef cattle feedlots are located. The greatest potential for transport of unconsolidated surface material occurs during periods with the largest precipitation. The quantity of material transported from feedlot surfaces could be reduced if unconsolidated surface material was removed prior to high precipitation periods.

\section{CONCLUSiOnS}

Beef cattle feedlots contain unconsolidated surface material, which varies across the pen surface with time during the production cycle. The volume of feedlot runoff control structures should be large enough to store the amount of sediment transported in runoff from the feedlot surface. This study was conducted to identify the hydraulic conditions that will not move unconsolidated surface material located within feedlots in order to minimize sediment transport.

The ratio of critical flow depth to particle diameter was less than one for each of the particle size classes and the composite material. Thus, unconsolidated surface material is not submerged before drag forces become large enough to cause particle movement. Critical shear velocity, critical Reynolds number, critical shear stress, and critical boundary Reynolds number increased in a linear fashion with particle diameter, as indicated by the regression relationships derived for each of these variables.

Darcy-Weisbach roughness coefficients increased with Reynolds number for the tests conducted on the surface with unconsolidated material having a mean diameter of $1.59 \mathrm{~mm}$. In contrast, Darcy-Weisbach roughness coefficients derived for each of the other size classes and the composite sample decreased in an exponential fashion with particle diameter. The hydraulic conditions required to not move unconsolidated surface material located within feedlots are identified in this investigation.

\section{REFERENCES}

Abrahams, A. D., A. J. Parsons, and S. H. Luk. 1986. Resistance to overland flow on desert hillslopes. J. Hydrol. 88(3): 343-363.

ASABE Standards. 2009. S292.5: Uniform terminology for rural waste management. St. Joseph, Mich.: ASABE.

Blake, G. R., and K. H. Hartge. 1986. Particle density. In Methods of Soil Analysis: Part 1. Physical and Mineralogical Methods, 377-382. A. Klute, ed. Madison, Wisc.: ASA.

Chow, V. T. 1959. Open Channel Hydraulics. New York, N.Y.: McGraw-Hill.

Clanton, C. J., M. I. Endres, R. F. Bey, R. J. Farnsworth, K. A. Janni, and D. R. Schmidt. 2005. Dolomitic limestone bedding effects on microbial counts and cow comfort. Applied Eng. in Agric. 21(6): 1073-1077.

Clark, R. N., A. D. Schneider, and B. A. Stewart. 1975. Analysis of runoff from southern Great Plains feedlots. Trans. ASAE 18(2): 319-322.

Engman, E. T. 1986. Roughness coefficients for routing surface runoff. J. Irrig. Drainage Eng. ASCE 112(1): 39-53.

Foster, G. R., L. F. Huggins, and L. D. Meyer. 1968. Simulation of overland flow on short field plots. Water Resources Res. 4(6): 1179-1187.

Gilbertson, C. B., and J. A. Nienaber. 1973. Beef cattle feedlot runoff: Physical properties. Trans. ASAE 16(5): 997-1001.

Gilley, J. E., W. J. Elliot, J. M. Laflen, and J. R. Simanton. 1993. Critical shear stress and critical flow rates for initiation of rilling. J. Hydrol. 142(1-4): 251-271.

Gilley, J. E., E. D. Berry, R. A. Eigenberg, D. B. Marx, and B. L. Woodbury. 2008. Spatial variations in nutrient and microbial transport from feedlot surfaces. Trans. ASABE 51(2): 675-684.

Gilley, J. E., J. R. Vogel, E. D. Berry, R. A. Eigenberg, D. B. Marx, and B. L. Woodbury. 2009. Nutrient and bacterial transport in runoff from soil and pond ash amended feedlot surfaces. Trans. ASABE 52(6): 2077-2085.

Gilley, J. E., J. R. Vogel, R. A. Eigenberg, D. B. Marx, and B. L. Woodbury. 2011. Runoff, erosion, and size distribution of sediment from beef cattle feedlots. Trans. ASABE 54(2): 435440.

Ham, J. M. 1999. Measuring evaporation and seepage losses from lagoons used to contain animal waste. Trans. ASAE 42(5): 13031312.

Ham, J. M. 2002. Seepage losses from animal waste lagoons: A summary of a four-year investigation in Kansas. Trans. ASAE 45(4): 983-992.

Hillel, D. 1971. Soil and Water Physical Principles and Processes. New York, N.Y.: Academic Press.

Mielke, L. N., and A. P. Mazurak. 1976. Infiltration of water on a cattle feedlot. Trans. ASAE 19(2): 341-344.

Mielke, L. N., N. P. Swanson, and T. M. McCalla. 1974. Soil profile conditions of cattle feedlots. J. Environ. Qual. 3(1): 14-17.

Parker, D. B., D. E. Eisenhauer, D. D. Schulte, and D. L. Martin. 1999. Modeling seepage from an unlined beef cattle feedlot runoff storage pond. Trans. ASAE 42(5): 1437-1445.

Parker, D. B., J. E. Mehlhorn, M. S. Brown, and S. C. Bressler. 2004. Engineering properties and economics of soil cement feed yard surfacing. Trans. ASAE 47(5): 1645-1649.

Pepple, L. M., D. S. Andersen, R. T. Burns, and L. B. Moody. 2011. Physical and chemical properties of runoff effluent from beef feedlots in Iowa. Trans. ASABE 54(3): 1079-1084.

SAS. 2011. SAS/STAT User's Guide. Version 9.3. Vol. 1. 4th ed. Cary, N.C.: SAS Institute, Inc.

Simons, D. B., and F. Senturk. 1976. Sediment Transport Technology. Fort Collins, Colo.: Water Resources Publications.

Woodbury, B. L., D. N. Miller, J. A. Nienaber, and R. A. Eigenberg. 2001. Seasonal and spatial variations of denitrifying enzyme activity in feedlot soil. Trans. ASAE 44(6): 1635-1642.

Woolhiser, D. A., C. L. Hanson, and A. R. Kuhlman. 1970. Overland flow on rangeland watersheds. J. Hydrol. 9(2): 336356. 